\title{
Maternal fluid overload during labour; transplacental hyponatraemia and risk of transient neonatal tachypnoea in term infants
}

\author{
S C SINGHI AND E CHOOKANG \\ Departments of Child Health and Pathology, University of the West Indies, Kingston, Jamaica
}

SUMMARY Cord serum sodium concentrations in two groups of vaginally delivered, singleton term infants were correlated with the incidence of transient neonatal tachypnoea. Hyponatraemia (cord serum sodium less than $130 \mathrm{mmol} / \mathrm{l}$ ) was seen in 71 of $180(39 \%)$ infants born to mothers who received an intravenous infusion of aqueous glucose solution during labour (study group) compared with 6 of $103(6 \%)$ infants born to mothers who did not receive any intravenous fluid treatment (controls). The incidence of transient neonatal tachypnoea was 4.5 times higher for hyponatraemic infants in the study group (11 of 71) than for normonatraemic infants in the same group (3 of 109) and the control group (3 of 97). The difference was not attributable to other perinatal or neonatal characteristics. Our findings suggest an increased risk of transient neonatal tachypnoea in term infants who suffer from transplacental hyponatraemia after their mothers received intrapartum infusion of aqueous glucose solutions.

During labour women often receive an infusion of aqueous glucose solution for hydration or as a vehicle for oxytocin treatment. The possible ill effects, however, of this practice on the fetus and the neonates have not received much attention until recently. ${ }^{1}$ It is now recognised that this may cause transplacental hyponatraemia ${ }^{2-4}$ which in turn may be associated with convulsions, poor feeding, ${ }^{5}$ and increased risk of neonatal jaundice. ${ }^{67}$ We present findings which suggest an increased risk of transient neonatal tachypnoea ${ }^{8}$ (also called wet lung syndrome $\mathrm{e}^{9}$ ) in newborns who suffer from transplacental hyponatraemia after intrapartum glucose water infusion to the mother.

\section{Subjects and methods}

We studied two groups of infants from those who were delivered at the University Hospital of the West Indies, Kingston between March and June 1984. The first group, the study group, consisted of infants born to mothers who received intravenous infusion of aqueous glucose solution for hydration (glucose solution subgroup) or as a vehicle for oxytocin (oxytocin subgroup). A second group of infants whose mothers did not receive any intravenous fluid treatment during labour served as controls. Intrapartum fluid intake of the mothers in this group consisted of small sips of water. No formal randomisation was done. All the singletons delivered vaginally at term (gestation 37 weeks or more) during the study period were eligible. Attempts were made to include all the consecutive deliveries as far as possible, in their respective groups until there were at least 90 to 100 infants in each of the subgroups and in the control group. All the decisions regarding maternal fluid treatment were made by the attending obstetrician and were in no way influenced by the study. Detailed maternal and perinatal data were recorded by attending medical students or house staff, on a proforma in all the cases.

Gestational age was determined from the mothers' last menstrual period and was also assessed by physical and neurological criteria. In case of discrepancy, assessed gestational age was substituted. Informed consent was obtained from all the mothers, and the study was approved by the hospital ethical committee. Maternal and cord venous blood samples were obtained at the time of delivery (within 15 minutes) for determination of serum sodium by flame photometry (Technicon SMA6/60 Autoanalyser), serum osmolality was measured by freezing point depression (Advanced model-2 
osmometer) and serum total proteins and albumin by biuret and bromocresol green dye binding methods (GEMSAEC analyser).

The newborn infants were routinely observed by the resident and nursing staff, and those who developed respiratory distress (persistent tachypnoea 60 per minute or more, associated with or without grunting, retraction, or cyanosis) were transferred to the neonatal special care unit. From these infants, those who were diagnosed as having transient tachypnoea of the newborn, or wet lung syndrome by the attending physician were identified and their records were reviewed to make sure that they fulfilled the following criteria:

(i) Persistent tachypnoea (respiratory rate 60 per minute or more for over three hours) with onset within half an hour of birth;

(ii) Minimal grunting and retraction, with or without cyanosis in room air;

(iii) Necessity for oxygen therapy;

(iv) Spontaneous improvement starting within 24 hours of birth;

(v) Suggestive radiological findings.

Only when the above diagnostic criteria were fulfilled was the diagnosis accepted. Infants with the diagnosis of sepsis, congenital heart disease, pneumonia, and meconium aspiration syndrome were excluded from the analysis. Statistical analysis of the results was by $\chi^{2}$ (with Yates's correction), two tailed $t$ test, and calculation of Pearson's correlation coefficient.

\section{Results}

There were 186 infants in the study group (glucose solution subgroup, 91; oxytocin subgroup, 95) and 107 in the control group. Results from 10 infants (six study and four controls) were excluded from the analysis because of an assessed gestation less than 37 weeks (5), congenital malformations (1), sepsis (2), and birthweight less than $2500 \mathrm{~g}$ (2). This left 180 infants in the study group and 103 in the control group. The infants in the study and control groups did not differ in respect of maternal age, gestation, duration of labour, Apgar score, and birthweight; nor did the infants in the glucose solution and oxytocin subgroups of the study group differ in these respects. The latter subgroups of infants also did not differ in respect of average volume of intravenous infusion received by their mothers during labour (details presented elsewhere $^{7}$ ). About $90 \%$ of all the

Table 1 Incidence of transient tachypnoea of the newborn $(T T N)$ in study and control infants in relation to cord serum sodium concentrations

\begin{tabular}{|c|c|c|c|c|}
\hline \multirow{2}{*}{$\begin{array}{l}\text { Cord serum } \\
\text { sodium }(\mathrm{mmol} / \mathrm{l})\end{array}$} & \multicolumn{2}{|c|}{ Study group } & \multicolumn{2}{|c|}{ Control group } \\
\hline & Total & With TTN & Total & With TTNO \\
\hline 130 or less & 71 & $11(15 \%)^{*}$ & 6 & 0 \\
\hline 131 or above & 109 & $3(3 \%)$ & 97 & $3(3 \%)$ \\
\hline Total & 180 & $14(7 \cdot 8 \%)$ & 103 & $3(3 \%)$ \\
\hline
\end{tabular}

${ }^{*} \mathrm{P}<0 \cdot 005$, compared with infants with cord serum sodium $>131 \mathrm{mmol} / \mathrm{l}$.

Table 2 Perinatal and biochemical characteristics of study and control infants (values mean (SD))

\begin{tabular}{|c|c|c|c|c|}
\hline \multirow[t]{2}{*}{ Characteristics } & \multicolumn{2}{|l|}{ Study group } & \multicolumn{2}{|l|}{ Control group } \\
\hline & Hyponatraemic $(n=71)$ & Normonatraemic $(n=109)$ & Hyponatraemic $(n=6)$ & Normonatraemic $(n=97)$ \\
\hline \multicolumn{5}{|l|}{ Perinatal } \\
\hline Maternal age (years) & $23.4(4 \cdot 6)$ & $24 \cdot 5(5 \cdot 8)$ & $20 \cdot 1(3 \cdot 6)$ & $24 \cdot 5(4 \cdot 6)$ \\
\hline Gestation (weeks) & $39 \cdot 1(1 \cdot 2)$ & $39 \cdot 2(1.0)$ & $38 \cdot 8(2 \cdot 0)$ & $39.5(1.4)$ \\
\hline Birthweight (g) & $3152(483)$ & $3268(433)$ & $3013(576)$ & $3202(497)$ \\
\hline Duration of labour (hours) & $9.0(3.8)$ & $10 \cdot 4(5 \cdot 6)$ & $8.0(3.4)$ & $8 \cdot 1(3 \cdot 3)$ \\
\hline Apgar score $<6$ & 3 & 5 & 1 & 7 \\
\hline $\begin{array}{l}\text { Volume of glucose solution } \\
\text { received by mother }(\mathrm{ml})\end{array}$ & $1085(668)$ & $939(675)$ & - & - \\
\hline \multicolumn{5}{|l|}{ Cord serum concentrations* } \\
\hline Sodium (mmol/l) & $128.6(2.4)^{\dagger}$ & $134 \cdot 0(2 \cdot 7)$ & $129 \cdot 8(0 \cdot 4)$ & $135 \cdot 8(3 \cdot 0)$ \\
\hline Osmolality (mmol/kg) & $275 \cdot 0(7 \cdot 0)$ & $280.6(4 \cdot 3)$ & $275.0(0.0)$ & $280 \cdot 1(4 \cdot 5)$ \\
\hline Chloride $(\mathrm{mmol} / \mathrm{l})$ & $98.5(3.2)^{f}$ & $102 \cdot 0(3.4)$ & $99.7(2.5)$ & $101.8(3.4)$ \\
\hline Total proteins $(\mathrm{g} / \mathrm{l})$ & $58.4(4 \cdot 9) \ddagger$ & $60 \cdot 3(4 \cdot 1)$ & $63 \cdot 6(3 \cdot 1)$ & $60 \cdot 2(4 \cdot 5)$ \\
\hline Albumin $(g / l)$ & $38.9(3.4) \ddagger$ & $40 \cdot 7(3 \cdot 8)$ & $40 \cdot 3(1 \cdot 6)$ & $40 \cdot 3(3 \cdot 5)$ \\
\hline \multicolumn{5}{|c|}{ Maternal serum concentrations* } \\
\hline Sodium (mmol/l) & $129 \cdot 2(3 \cdot 8)^{\dagger}$ & $135 \cdot 0(2 \cdot 7)$ & $132 \cdot 1(3 \cdot 8)$ & $135 \cdot 7(3.4)$ \\
\hline Osmolality (mmol/kg) & $277.6(6.5)$ & $277 \cdot 5(4 \cdot 9)$ & $277 \cdot 5(4 \cdot 9)$ & $281 \cdot 0(4 \cdot 0)$ \\
\hline Chloride $(\mathrm{mmol} / \mathrm{l})$ & $99.8(3.3)^{f}$ & $102 \cdot 6(3 \cdot 4)$ & $100 \cdot 0(4 \cdot 0)$ & $102 \cdot 7(3 \cdot 5)$ \\
\hline
\end{tabular}

*Serum osmolality, total proteins, and albumin concentrations were measured in only 88 study infants ( 33 hyponatraemic and 55 normonatraemic) and 52 controls (3 hyponatraemic and 49 normonatraemic).

${ }^{\dagger} \mathrm{P}<0.05,{ }^{\ddagger} 0.1>\mathrm{P}>0.05$ by $t$ test, compared with normonatraemic infants. 
Table 3 Characteristics of 11 infants who had transient neonatal tachypnoea

\begin{tabular}{|c|c|c|c|c|c|c|c|c|c|}
\hline No & $\begin{array}{l}\text { Maternal age } \\
\text { (years) }\end{array}$ & $\begin{array}{l}\text { Gestation } \\
\text { (weeks) }\end{array}$ & $\begin{array}{l}\text { Birthweight } \\
\text { (g) }\end{array}$ & $\begin{array}{l}\text { Duration } \\
\text { of labour } \\
\text { (hours) }\end{array}$ & $\begin{array}{l}\text { Apgar score at } \\
5 \text { minutes }\end{array}$ & $\begin{array}{l}\text { Amount of glucose } \\
\text { solution }(\mathrm{ml})+ \\
\text { oxytocin received } \\
\text { (U) }\end{array}$ & $\begin{array}{l}\text { Duration of } \\
\text { respiratory } \\
\text { distress } \\
\text { (hrs) }\end{array}$ & $\begin{array}{l}\text { Duration of } \\
\text { oxygen therapy } \\
\text { (hrs) }\end{array}$ & $\begin{array}{l}\text { Cord serum } \\
\text { sodium } \\
(\mathrm{mmol} / \mathrm{l})\end{array}$ \\
\hline 1 & 32 & 40 & 3165 & $10 \cdot 3$ & 10 & 1000 & 24 & 18 & 123 \\
\hline 2 & 19 & 40 & 2710 & & 8 & $1750+2 \cdot 5$ & 20 & $<12$ & 130 \\
\hline 3 & 19 & 39 & 3800 & 4.9 & 9 & $2550+10$ & 30 & 24 & 130 \\
\hline 4 & 23 & 37 & 2680 & $2 \cdot 3$ & 10 & 1500 & 24 & 24 & 119 \\
\hline 6 & 28 & 40 & 2880 & $6 \cdot 2$ & 10 & $1200+5$ & 24 & 12 & 128 \\
\hline 7 & 17 & 39 & 3430 & $8 \cdot 1$ & 10 & 1000 & 25 & 15 & 129 \\
\hline 8 & 24 & 38 & 3140 & 8.7 & 9 & $1550+5$ & 36 & 16 & 128 \\
\hline 9 & 26 & 39 & 3020 & 9.2 & 10 & 1200 & 48 & 26 & 125 \\
\hline 10 & 20 & 38 & 2980 & $10 \cdot 0$ & 9 & 1800 & 28 & 20 & 127 \\
\hline 11 & 29 & 40 & 3200 & $7 \cdot 1$ & 10 & $2000+10$ & 36 & 12 & 130 \\
\hline
\end{tabular}

intravenous fluid infused was $5 \%$ solution of glucose in water, the rest was a $10 \%$ solution.

Hyponatraemia defined as serum sodium concentration of $130 \mathrm{mmol} / \mathrm{l}$ or less, was seen in $39 \%$ (71 of 180) of the infants in the study group at the time of birth. This was significantly higher than the incidence of $6 \%$ (6 of 103) in the control group $(\mathrm{P}<0 \cdot 01)$.

Transient neonatal tachypnoea was diagnosed in $15 \%$ (11 of 71 ) of the hyponatraemic infants in the study group. This was significantly higher than the incidence of transient neonatal tachypnoea in the normonatraemic infants in the same group (3 of 109) $(\mathrm{P}<0.005)$ and the control group ( 3 of 97) $(\mathrm{P}<0.005)$ (Table 1). The hyponatraemic and normonatraemic infants did not differ in respect of gestation, birthweight, duration of labour, and Apgar score (Table 2).

Details of 11 hyponatraemic infants who suffered from transient neonatal tachypnoea are shown in Table 3. Of importance are the facts that the average volume of glucose solution received by mothers of these infants was higher (mean (SD) $1495(570) \mathrm{ml}$ ) and the cord serum sodium concentration was lower (mean (SD) $126.7(3.5) \mathrm{mmol} / \mathrm{l}$ ) than for the hyponatraemic study group infants on the whole.

A statistically significant negative correlation was observed between the volume of glucose solution the mother received and the maternal and cord serum sodium ( $\mathrm{r}:-0.56, \mathrm{P}<0.0001)$ (Figure). In a subsample of 140 infants ( 88 study and 52 control infants) which did not differ from the total sample in respect of maternal, perinatal, and neonatal details, significant correlations were also seen between volume of intravenous glucose solution administered to the mother and cord serum osmolality ( $\mathrm{r}$ : $-0.32, \mathrm{P}<0.0025)$ and albumin $(\mathrm{r}:-0.24, \mathrm{P}<0.05)$. The dilutional nature of this hyponatraemia was evident by concurrent lowering of about 3 to $5 \%$ in

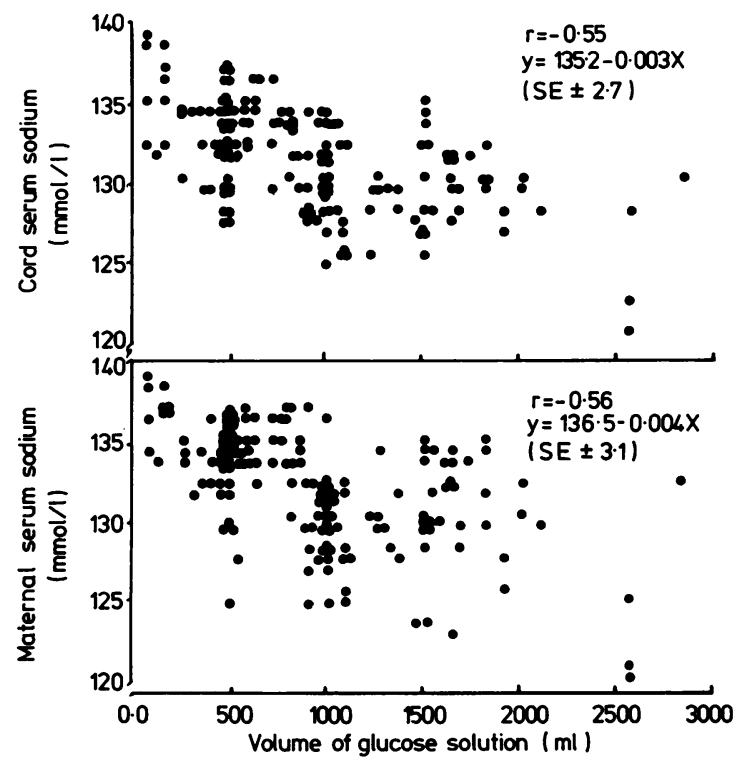

Figure Relation between the volume of glucose solution received by mothers and maternal and cord serum sodium concentrations at the time of delivery.

the concentration of cord serum total protein, albumin, chloride, and osmolality in the hyponatraemic neonates compared with the normonatraemic infants (Table 2 ).

\section{Discussion}

We found an increased incidence of transplacental hyponatraemia in infants whose mothers received aqueous glucose solution (with or without oxytocin) during labour. This is consistent with the findings of previous studies. ${ }^{2-5}$ The relative contribution of the volume of glucose-water, dose of oxytocin, and rate 
of infusions in the causation of hyponatraemia has been reported in a separate communication. ${ }^{10}$ Our observations, however, suggest an increased risk of transient neonatal tachypnoea in the hyponatraemic infants-an association that has not been documented previously.

Normally, soon after birth, excessive alveolar and interstitial fluid from the newborn's lung is rapidly absorbed and drained by way of the venous circulation and lymphatics. ${ }^{11} 12 \mathrm{~A}$ delay in this process has been identified as the most probable mechanism causing transient neonatal tachypnoea. ${ }^{13}{ }^{14}$ Many factors determine the rate of this pulmonary fluid absorption, of which plasma osmotic pressure is an important one. A fall in plasma osmotic pressure is thus likely to delay the fluid absorption. We suggest that this could be one of the reasons for the observed increase in the frequency of tachypnoea in the hyponatraemic compared with normonatraemic infants in this study. Our assumption is supported by the findings of significantly low serum osmolality and marginally low serum total proteins and albumin concentrations in the hyponatraemic neonates compared with normonatraemic neonates. Moreover, these changes in the biochemical constituents of serum were significantly related to the volume of glucose solution received by the mother just before delivery. Indeed, Kero et $a l^{15}$ in a recent report suggest that cord plasma oncotic pressure is lower in infants who develop transient tachypnoea than in healthy infants of the same gestational age.

Strang ${ }^{12}(1982)$ has shown that the sodium pump is important in adrenaline induced reabsorption of pulmonary fluid soon after birth. It is possible that the function of this pump is impaired in the presence of hyponatraemia which may further delay the pulmonary fluid absorption. This aspect needs to be studied further.

Our finding also offers one more explanation for the increased incidence of transient neonatal tachypnoea in the infants delivered by caesarean section; they have been shown to have significantly lower mean plasma oncotic pressure at birth ${ }^{15} 16$ and are usually born to mothers receiving large volumes of fluid in the intrapartum period.

We thank the sisters and nursing staff of the labour ward, medical students, and Drs G Smith and G Banbury in completion of this study. We are also grateful to Professor $\mathrm{H}$ Wynter, for permission to study the patients admitted to the labour wards, to Mr Bailey, for helping with statistical analysis of the data, and Mrs E Males and Miss J DeSouza for typing the paper.

\section{References}

1 Oski FA. In: Oski FA, Stockman JA, eds. Year book of paediatrics-1983. Chicago: Yearbook Medical Publishers, 1983;39.

2 Singhi S, Singh M. Asymptomatic transplacental hyponatraemia following oxytocin infusion during labour. Indian J Med Res 1979;70:55.7.

${ }^{3}$ Dahlenburg GW, Burnell RH, Braybrook R. The relationship between cord serum sodium levels in newborn infants and maternal intravenous fluid therapy. Br J Obstet Gynaecol 1980;87:519-22.

4 Tarnow-Mordi WO, Shaw JCL, Lin D, Gardner DA, Flynn FV. Iatrogenic hyponatraemia of newborn due to maternal fluid overload; a prospective study. $\mathrm{Br}$ Med $J$ 1981;283:639-42.

${ }^{5}$ Spencer SA, Mann NP, Smith ML, Woolfson AMJ. The effect of intravenous therapy during labour on maternal and cord serum sodium levels. Br J Obstet Gynaecol 1981;80:480-3.

6 Singhi S, Chookang E, Hall J, St E. Hazards of maternal hydration with five percent dextrose water. Lancet 1982;ii: 335-6.

7 Singhi S, Chookang E, Hall J, St E. Intrapartum infusion of aqueous glucose solution, transplacental hyponatraemia and risk of neonatal jaundice. Br J Obstet Gynaecol 1984;91:(In press).

8 Avery ME, Gatewood OB, Brumley G. Transient tachypnoea of newborn. Am J Dis Child 1966;111:380-5.

9 Wesenberg RL, Graven SN, McCabe EB. Radiological findings in wet lung disease. Radiology 1971;98:69-74.

10 Singhi S, Chookang E, Hall J, St E. Transplacental hyponatraemia following intrapartum infusion of aqueous glucose solution and oxytocin. Br J Obstet Gynaecol 1984;91:(In press).

11 Humphreys PW, Normand ICS, Reynolds EOR, Strang LB. Pulmonary lymph flow and up-take of liquid from the lungs of lamb at the start of breathing. $J$ Physiol 1967;193:1-29.

12 Strang LB. Formation and absorption of liquids in the lung: lessons from the foetus. Advanced Medicine 1982;16:434.46.

13 Oh W, Stern L. Disease of respiratory system. In: Behrman RE, Driscoll L, eds. Neonatal-perinatal medicine. 2nd ed. St Louis: CV Mosby, 1977:562-3.

14 Avery ME. Miscellaneous pulmonary disorders. In: Shaffer AJ, Avery ME, eds. Disease of the newborn. Philadelphia: WB Saunders, 1977;171-2.

15 Kero P, Korvenrenta H, Alamaakala P, Selanne P, Kilholma P, Valmaki I. Colloid osmotic pressure of cord blood in relation to neonatal outcome and mode of delivery. Acta Paediatr Scand 1983;Suppl 305:88-91.

${ }^{16}$ Loeb P, Lesli GI, McDevitt M, Cassady G. Colloid osmotic pressure at birth. Am J Dis Child 1983;137:647-57.

Correspondence to Dr S C Singhi, 1239 Officer's Appartments, Sector 24, Chandigarh 160024, India.

Received 30 August 1984 